\title{
Determinants of Total Factor Productivity, Technological Change, and Efficiency Differentials Among States, 1977-86
}

\author{
Bruce R. Domazlicky and William L. Weber*
}

\begin{abstract}
Significant differences in the growth rates of total factor productivity (TFP) exist among states. In this study, the sources of differences in TFP growth, technological change, and average efficiency levels for states in the period 1977-86 are identified. Rather than focusing on just the manufacturing sector, the present study is concerned with TFP growth and technological change for all (aggregated) sectors. Results from the study indicate that policies to attract manufacturing industries and private capital will increase TFP growth, primarily by increasing technological change. States with lower levels of production efficiency can move closer to their production frontiers by improving the quality of the labor force (education, for example), attracting private capital and, in the case of states with very large metropolitan areas, by encouraging the decentralization of economic activity.
\end{abstract}

\section{INTRODUCTION}

In a mature economy such as the United States, total factor productivity (TFP) growth, which measures output growth that is not attributable to input growth, may be the deciding factor as to whether living standards continue to improve. The measurement of TFP growth, both at the national level and at the regional level, is, therefore, an important undertaking. Many studies have measured TFP growth at the regional level for the manufacturing sector. (Hulten and Schwab 1984; Moomaw and Williams 1991; and Beeson 1987 are examples of such studies.) Recently, Domazlicky and Weber (1997) measured TFP growth for all sectors (aggregated) for the 48 contiguous states during the period 1977-86. Unlike earlier researchers who employed econometric or sources-of-growth approaches, Domazlicky and Weber used linear programming techniques to construct the Malmquist productivity index for each of the 48 states. In addition, measures of technological change during the 1977-86 period and of the average efficiency level over that period were also developed. The estimates of TFP growth and efficiency levels from that study are the dependent variables in the present study (see Table 3).

Once researchers have documented significant differences in state growth rates of TFP in manufacturing, the next logical step is to discover the determinants of those differences (see, for example, Beeson 1987; Moomaw and Williams 1991; Mullen and Williams 1990; Williams and Moomaw 1989; Beeson and Husted 1989; and McCoy and Moomaw 1995). With respect to policy, it is likely that some of the

"Professors, Southeast Missouri State University. 
determinants that are ultimately identified may be influenced by government, either directly or indirectly (through tax breaks or outright subsidies, for example), making the identification of the determinants a fruitful exercise. In this article, we attempt to identify the determinants of regional differences in TFP growth, technological change, and efficiency levels for total output, or Gross State Product. To our knowledge, this is the first study that is concerned with explaining such differences for entire state economies, as opposed to just the manufacturing sector.

The organization of this paper is as follows. In the next section, a brief review of the literature is given, with an emphasis on recent studies that have identified the determinants of regional differences in TFP. In section III, the methodology used to measure differences in TFP growth, technological change, and efficiency levels among states is explained briefly. The fourth section is used to present the determinants of such differences that we have identified. The final section presents a brief summary of our major conclusions.

\section{RESEARCH EXPLAINING REGIONAL DIFFERENCES IN TFP GROWTH}

Table 1 lists six recent studies that have explored the determinants of regional differences in TFP growth, efficiency levels, and/or technological change and also indicates the results of the studies by noting the significant variables used by researchers. In general, the studies use a sources-of-growth approach to estimate TFP growth. In the two studies where the efficiency level is estimated (McCoy and Moomaw 1995 and Beeson and Husted 1989), stochastic methods are employed to estimate production frontiers. Note that not all significant variables are necessarily listed for each study in Table 1. Rather, the emphasis is upon those variables that have been used most frequently in previous studies. The variables employed by the researchers are not necessarily identical; therefore, general categories of variables are given, of which eight categories appear most frequently: output growth, population or metropolitan population, education, unionization, regional, capital or the capital-labor ratio, industry structure, and labor force.

The actual forms of the variables that are employed include size (population), ratio (such as the percent of population in metropolitan areas or the percent of the labor force that is unionized), and growth rate (average annual growth rate of: capital; output; the proportion of females in the labor force). The selection of a particular form appears to be a matter both of convenience (what data are available) and significance (what variables appear to be statistically significant). Since economic theory does not indicate a particular form for a variable, the selection process involving form and inclusion of a variable must remain flexible.

Output growth has been employed as an explanatory variable by several researchers. There is evidence that productivity growth depends on the size of the market or, perhaps, the rate of growth of the market. Scale economies, in particular, may become significant as the size of the market increases. Either the volume of output or the rate of growth of output is used as a proxy for the influence of market size or market growth on productivity growth. All three studies that used 
output growth as an independent variable report a positive relationship between output growth and TFP growth.

TABLE 1

Classification of Studies

\begin{tabular}{|c|c|c|c|c|c|c|}
\hline & $\begin{array}{l}\text { McCoy } \\
\text { Moomaw }\end{array}$ & $\begin{array}{l}\text { Beeson } \\
\text { Husted }\end{array}$ & $\begin{array}{l}\text { Williams } \\
\text { Moomaw }\end{array}$ & $\begin{array}{l}\text { Mullen } \\
\text { Williams }\end{array}$ & $\begin{array}{l}\text { Moomaw } \\
\text { Williams }\end{array}$ & Beeson \\
\hline Region & Cities & States & States & 29 Cities & States & States \\
\hline Time & $1976-80$ & $1959-73$ & $1954-72$ & $1958-78$ & $1954-76$ & $1959-73$ \\
\hline DV & EFFIC & EFFIC & TFP & TFP & TFP & $\begin{array}{l}\text { TFP, } \\
\text { TECH }\end{array}$ \\
\hline Output & & & $x$ & $x$ & $x$ & \\
\hline Metro & $x$ & $x$ & & & $X$ & $\mathrm{X}$ \\
\hline Educ & $\mathrm{X}$ & $x$ & & & $x$ & \\
\hline Union & & $x$ & $X$ & $x$ & $X$ & \\
\hline Region & $\mathrm{X}$ & & & & & \\
\hline Capital & & & $x$ & $\mathrm{X}$ & & \\
\hline Struct & & $x$ & & & & $\mathrm{X}$ \\
\hline LF & $x$ & & & $\mathrm{X}$ & $X$ & \\
\hline
\end{tabular}

DV = Dependent Variable

TFP = Total Factor Productivity

TECH $=$ Growth rate of technological change

EFFIC $=$ Efficiency level

Output = Manufacturing output (usually value added)

Metro = Metropolitan population or population

Educ $=$ Education

Capital $=$ Capital stock or capital-labor ratio

Struct $=$ Industrial Structure

LF $=$ Labor Force

Population or metropolitan population variables that have been employed by earlier researchers include size, percent of population that lives in a metropolitan area, average size of metropolitan areas, and a dummy variable developed by Beeson (1987), which takes a value of one if the state contains one of the twenty largest metropolitan areas. The dummy variable used by Beeson and also by Moomaw and Williams (1991) is positively and significantly related to TFP growth in both studies. Beeson hypothesizes that the variable is indicative of a "...hierarchical diffusion of technology at least among the largest urban areas." (Beeson 1987, p. 193) Mullen and Williams find that population growth is negatively related to TFP growth, a relationship they attribute to the existence of external agglomeration diseconomies in large urban areas. Moomaw and Williams find a negative relationship between the average size of metropolitan areas in a state and TFP growth. They suggest that smaller metropolitan areas have experienced faster TFP growth that could be due to the "...dispersion of agglomeration economies to smaller urban areas..." (Moomaw and Williams 1991, p. 26). The evidence from earlier studies gives some indication that urban areas possess advantages in generating TFP growth and technological change, but those advantages could be lost if an urban area becomes too large and experiences agglomeration diseconomies.

Education variables used by previous researchers include the percent of the population (or manufacturing workforce) with at least 12 years of schooling, median 
school years completed, and the growth rate of the previous variable. Most research indicates that there is a positive and significant relationship between some measure of education and TFP growth or the efficiency level of manufacturing.

The most commonly used form of the effects of unions is the proportion of the labor force that is unionized. Moomaw and Williams (1991) also employ the number of work stoppages, though it is not significant. Most previous research indicates a positive relationship between unionization and TFP growth, which, perhaps, may be indicative of better worker morale in a union environment.

Recent capital stock growth (1974-78) is a variable used by Mullen and Williams (1990). They attribute the negative and significant relationship between recent capital stock growth and TFP growth to firms acquiring capital as a response to government regulations and to rising energy prices in the 1970s. They also tested two variables that related to local government investment (for highways and for water pollution control), but neither was significant. Williams and Moomaw (1989) also use the growth rate of the capital-labor ratio as an explanatory variable and find it to be positively related to TFP growth. They hypothesize that "...increases in the capital-labor ratio imply a greater intensity of the use of new capital equipment which may embody more efficient technology." (Williams and Moomaw 1989, p. 578.)

In two studies, industry structure is represented by the proportion of durable goods in manufacturing. While Beeson (1987) gets mixed results, there is a positive and significant relationship between industry structure and efficiency levels in manufacturing in the study by Beeson and Husted (1989). McCoy and Moomaw (1995) use the unemployment rate and the proportion of the labor force that is male as proxies for industry structure. While their results are as expected (positive relationship for male labor force proportion, negative for unemployment rate), it is not clear that these two variables are satisfactory measures of industry structure in a city.

Labor force variables that are used in some studies include the proportion of the labor force that is female, old, young, and professional/technical workers. To the extent that labor force participants may lack significant experience (young and females), or possess declining skills (older workers), TFP growth may be adversely affected. It would be expected that a higher proportion of professional/ technical workers would increase TFP growth, but Moomaw and Williams (1991) actually find a negative relationship.

After accounting for the influence of the preceding variables, differences in TFP growth that are due to regional factors may still remain. For the U.S., Beeson and Husted (1989) find that states in the manufacturing belt have lower levels of efficiency. McCoy and Moomaw (1995) get the opposite result for cities in Canada's manufacturing belt.

Several policy conclusions can be drawn from the experience of previous researchers. Improvements in education, a variable directly controlled by government, will lead to higher growth rates of TFP. Special tax breaks or 
subsidies to encourage private investment in capital goods will also be fruitful. There is evidence that agglomeration diseconomies have been an impediment to TFP growth in large urban areas; therefore, land-use controls such as zoning, or indirect controls such as subsidies for locating in less densely populated regions, may be useful in mitigating some of the effects of diseconomies. Likewise, government programs to improve or enhance the abilities of certain labor force participants could also help to improve TFP growth.

The experience of earlier researchers indicates that the eight general categories in Table 1 are the most fruitful ones to explore. Similar variables are used in this study to explain regional differences in TFP growth: technological growth, pure technical efficiency growth and efficiency levels.

\section{ESTIMATING TOTAL FACTOR PRODUCTIVITY GROWTH: METHODOLOGY}

In this section, we give a brief, intuitive explanation of the nonparametric linear programming techniques that are employed to construct measures of state productivity change. A more detailed explanation of the approach can be found in Domazlicky and Weber (1997) and in Fare, et al. (1994). Linear programming techniques envelop the data and define the best practice reference technology without imposing a restrictive functional form. The observed values of inputs and outputs for all of the states in each year are used to construct the reference technology.

The output distance function is central to the construction of state efficiency and productivity measures. A multiple input, multiple output production technology can be estimated through use of the distance function. Let $\mathbf{u}^{t}=\left(u_{1}{ }^{t}, \ldots, u_{m}{ }^{t}\right)$ be a vector of $m$ outputs and $x^{t}=\left(x_{1}^{t}, \ldots, x_{n}^{t}\right)$ be a vector of $n$ inputs. Define the production possibilities set for $\mathbf{x}^{t}$ to be $\mathrm{P}^{t}\left(\mathbf{x}^{t}\right)$, which gives all the combinations of $\mathbf{u}^{t}$ that can be produced from $x$. The output distance function is then defined as:

$D_{0}{ }^{t}\left(\mathbf{u}^{t}, \mathbf{x}^{t}\right)=\min \mathbf{l}^{t}$ subject to the requirement that $\mathbf{u}^{t} / 1^{t}$ is an element of $P\left(\mathbf{x}^{t}\right)$

The value of the output distance function is the measure of technical efficiency for each state relative to the best practice reference technology for all states for time $t$. If a state is operating on its production possibility set at time $t$, then $1^{t}$ is equal to one. A state that is operating inside of its production possibility set will have an $1^{t}$ that is less than one. The distance function, $1^{t}$, gives the ratio of the state's actual output to its hypothetical, maximum output at time $t$, and serves as a measure of technical efficiency for the state. The reciprocal of the distance function, $\left(\mathrm{l}^{t}\right)^{-1}$ gives the maximum proportional expansion of each output given the state's level of input usage.

The linear programming technique generates a level of technical efficiency (which is less than or equal to one) for each state for each time period. The reasons for regional variations in the average efficiency levels of states for the ten-year period, 1977-86, are explored in Section IV of the paper.

The level of technical efficiency for a state in each time period can be decomposed into a measure of scale efficiency and a measure of pure technical 
efficiency. If a state is not operating in the range of constant returns to scale, then theoretically it could increase output without increases in input if constant returns to scale were achieved. Pure technical efficiency occurs when a state operates on its production frontier. Overall technical efficiency is the product of scale efficiency and pure technical efficiency.

The output distance function is also used to construct the Malmquist productivity index developed by Caves, et al. (1982) to measure TFP for multioutput, multi-input production technologies. TFP in a state increases over time due to improvements in overall technical efficiency (moving closer to the state's production frontier) and due to technological change (outward shifts of the state's production frontier). Fare et al., (1994) show that TFP change is the product of changes in efficiency and in technological progress.

Consider the production frontiers in Figure 1 in the case of two outputs, $u_{1}$ and $u_{2}$. In period $t$, the reference technology is bounded by OGBNH and the state is at the observed output combination represented by point $A$. In period $t+1$, the reference technology has shifted out and is bounded by OJKFM. The state in period $t+1$ operates at the output combination represented by point $E$. A productivity index could be constructed by examining the output combinations in period $t$ and $t+1$ with respect to the reference technology of period $t$ or period $t+1$. If the reference technology of period $t$ is used, then productivity change could be measured as:

$$
\mathrm{M}^{\mathrm{t}}=(\mathrm{OE} / \mathrm{OD}) /(\mathrm{OA} / \mathrm{OB})
$$

Alternatively, if the reference technology of period $t+1$ is used, then the measure of productivity change becomes:

$$
\mathrm{M}^{\mathrm{t}+1}=(\mathrm{OE} / \mathrm{OF}) /(\mathrm{OA} / \mathrm{OC})
$$

In (2), the output and input vectors of period $t+1$ are evaluated relative to the technology in period $t$. The denominator in (2) is the value of the distance function in period $t$. In (3), the numerator is the value of the distance function in period $t+1$ and the denominator evaluates the output and input vectors in period $t$ relative to the production frontier in period $t+1$.

In order to avoid the arbitrary choice of a base period from using either (2) or (3), the geometric mean of (2) and (3) is taken to yield the Malmquist productivity index:

$$
\mathrm{MALM}=[((\mathrm{OE} / \mathrm{OD}) /(\mathrm{OA} / \mathrm{OB})\} \times\{(\mathrm{OE} / \mathrm{OF}) /(\mathrm{OA} / \mathrm{OC})\}]^{0.5}
$$

which can be rearranged and written as:

$$
\mathrm{MALM}=\{(\mathrm{OE} / \mathrm{OF}) /(\mathrm{OA} / \mathrm{OB})\} \times[(\mathrm{OF} / \mathrm{OD}) /(\mathrm{OC} / \mathrm{OB})]^{0.5}
$$

The term outside of the brackets corresponds to the technical efficiency change from period $t$ to period $t+1$. A value greater than one means that technical efficiency has increased over time. The term inside of the brackets is the index of technological change measuring the shift in the production frontier from period $t$ 
Determinants of Total Factor Productivity, Technological Change, Efficiency 25

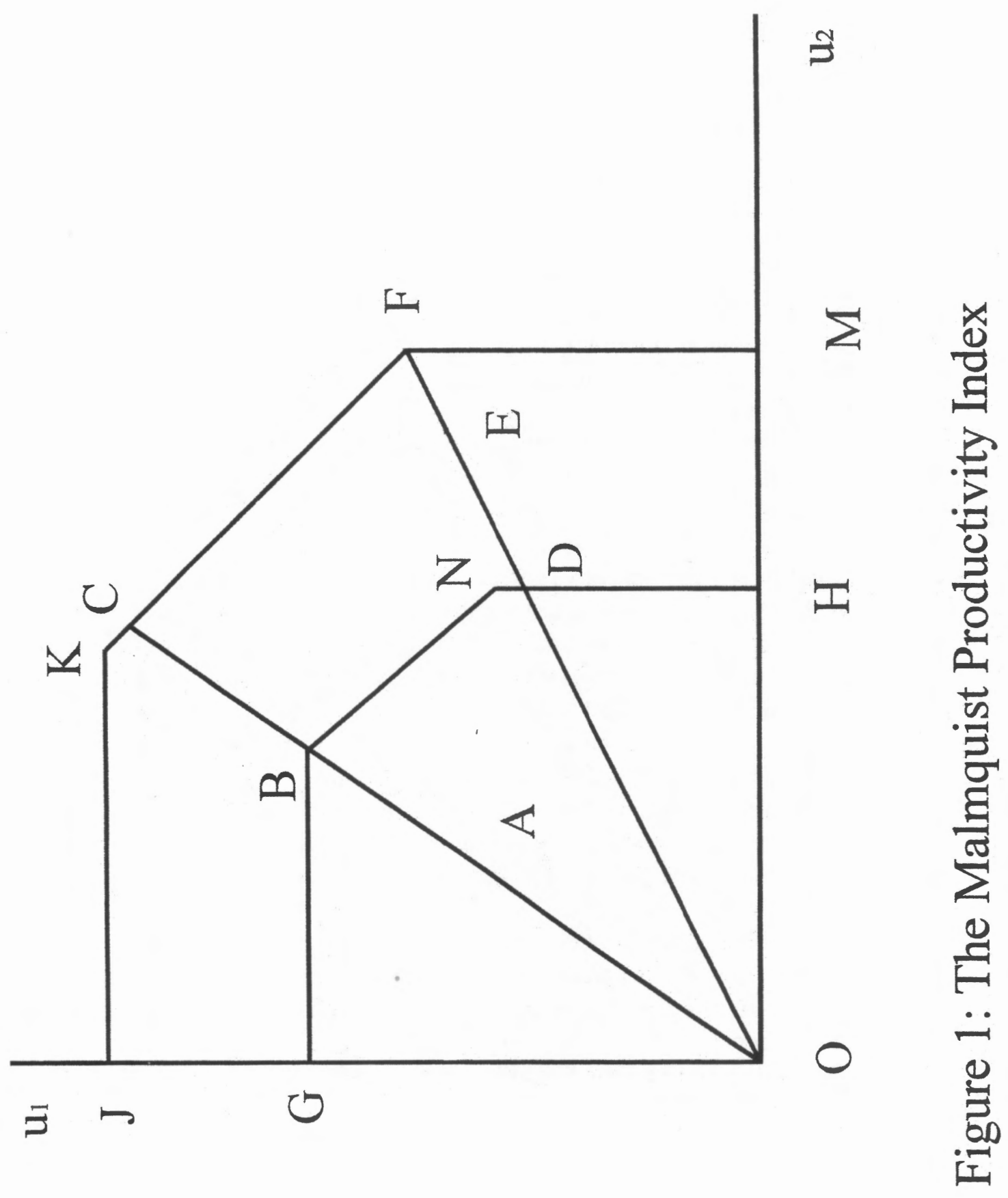


to period $t+1$. A value greater than one indicates technological progress and a value less than one indicates technological regress. In the next section, we explore the reasons for regional variations in the Malmquist productivity index and one of its components, technological change.

\section{DATA AND EMPIRICAL RESULTS}

The period of study, 1977 to 1986, is sufficiently long to allow productivity trends to be evident. The period starts and ends in similar phases of a business cycle so that cyclical effects should not overwhelm the beginning and ending estimates. Two outputs, private sector output and public sector output, and four inputs, private capital, public capital, private labor and public labor, are included in the model. The data for the outputs and inputs are taken from several sources. Data on public and private gross state product (GSP) are from a CD-ROM disk published by the Bureau of Economic Analysis. The CD-ROM is titled Regional Economic Information System and was published in May 1991. Public and private employment data were obtained from the Handbook of Labor Statistics (U.S. Department of Labor 1989). Capital stock data are not available at the state level, but estimates of such data have been made. Holtz-Eakin (1993) provided his estimates of public capital and Munnell (1990) shared her estimates of private capital that are described in the appendix to her 1990 article. All monetary figures are in 1982 dollars.

The last three columns of Table 3 list the average annual growth rates (one has been added to the growth rates for ease of interpretation) during 1977-86 of the Malmquist productivity index, of technological change, and of pure technical efficiency. A value greater than one denotes improvement over time while a value below one indicates deteriorating performance. Average efficiency levels of production for 1977-86 are given in the second column of Table 3. These levels were estimated by solving a sequence of linear programming problems described in Domazlicky and Weber (1997). The maximum value for efficiency is one, which indicates that a state operated on its production frontier for the entire period. Nine states have an efficiency level of one. The state that operated farthest from its production frontier during the period was Vermont with an efficiency level of 0.7883 or $78.83 \%$ of its theoretical maximum. A state that operated on its production frontier for all ten years experienced zero efficiency growth. This means that all of the state's TFP growth was due to technological change (MALM $=\mathrm{TECH}$ in Table 3).

The interregional differences in the four variables in Table 3 are the focus of interest in the present study. The four variables MALM, TECH, EFFCH, and EFFICIENCY are the dependent variables in successive ordinary least-squares regressions.

Table 2 lists the variables, definitions, and the expected signs (in the case of independent variables) that are used in the present study. Since these variables are drawn from the same categories used by previous researchers, only a few additional comments are required. First, an additional variable relating to the 
percent of a state's population with at least a high school education was tried, but was never significant in any of the regressions and so was dropped in favor of the college variable. Second, the professional/technical worker percentage of the labor force never attained significance and also was dropped from further consideration. Third, because of multicollinearity concerns, the growth rates of output and of public and private capital are not included in the same regression.

TABLE 2

List of Variables

Dependent Variables Definition

\begin{tabular}{|c|c|c|}
\hline EFFICIENCY & \multicolumn{2}{|l|}{ Average efficiency level of state, $1977-86$} \\
\hline MALM & \multicolumn{2}{|l|}{ Average annual growth rate of total factor productivity, 1977-86 } \\
\hline TECH & Average annual growth rate of technological change, 1977-86 & \\
\hline EFFCH & Average annual growth rate of pure technical efficiency change & ige, 1977-86 \\
\hline Independent Variables & Definition & xpected Sign \\
\hline COLLEGE & $\begin{array}{l}\text { Log of percent of population } 25 \text { years or older } \\
\text { with at least a bachelor's degree, } 1980\end{array}$ & + \\
\hline MFG & $\begin{array}{l}\text { Log of percent of a state's output that is in } \\
\text { the manufacturing sector, } 1986\end{array}$ & + \\
\hline UNION & $\begin{array}{l}\text { Growth rate of the percent of the labor force that } \\
\text { is unionized, } 1977-86\end{array}$ & ? \\
\hline UNIONA & Log of percent of labor force that is unionized, 1980 & ? \\
\hline METRO & $\begin{array}{l}\text { Average annual growth rate of a state's } \\
\text { metropolitan population, } 1977-86\end{array}$ & ? \\
\hline METROA & $\begin{array}{l}\text { Log of percent of a state's population in } \\
\text { metropolitan areas, } 1980\end{array}$ & $?$ \\
\hline TOP20 & $\begin{array}{l}\text { Dummy variable that is one for states with a } \\
\text { area that is among the twenty largest in the United States, } 1980\end{array}$ & 80 \\
\hline CAPPRIV & $\begin{array}{l}\text { Average annual growth rate of private capital } \\
\text { stock, 1977-86 }\end{array}$ & + \\
\hline CAPPUBLIC & $\begin{array}{l}\text { Average annual growth rate of public capital } \\
\text { stock, 1977-86 }\end{array}$ & $?$ \\
\hline EFF1977 & Efficiency level of a state in 1977 & - \\
\hline FEMALE & $\begin{array}{l}\text { Average annual growth rate of the proportion of a } \\
\text { state's labor force that is female, } 1977-86\end{array}$ & - \\
\hline OUTPUT & Average annual growth rate of GSP, 1977-86 & + \\
\hline SUNBELT & $\begin{array}{l}\text { Dummy variable that is equal to one for states } \\
\text { in southeast or southwest regions (BEA regions) }\end{array}$ & $?$ \\
\hline
\end{tabular}


TABLE 3

Dependent Variables

\begin{tabular}{|c|c|c|c|c|}
\hline STATE & EFFICIENCY & MALM & $\mathrm{TECH}$ & $\mathrm{EFFCH}$ \\
\hline$\overline{\mathrm{AL}}$ & 0.8175 & 1.0098 & 1.0032 & 1.0078 \\
\hline $\mathrm{AZ}$ & 0.8999 & 1.0039 & 1.0033 & 1.0017 \\
\hline AR & 0.8185 & 1.0128 & 1.0058 & 1.0043 \\
\hline CA & 1.0000 & 1.0044 & 1.0044 & 1.0000 \\
\hline $\mathrm{CO}$ & 0.9279 & 1.0006 & 1.0039 & 0.9961 \\
\hline CT & 1.0000 & 1.0155 & 1.0155 & 1.0000 \\
\hline $\mathrm{DE}$ & 0.8543 & 0.9954 & 1.0097 & 1.0000 \\
\hline FL & 0.9014 & 1.0079 & 1.0121 & 0.9959 \\
\hline GA & 0.8621 & 1.0096 & 1.0129 & 0.9966 \\
\hline ID & 0.8212 & 1.0047 & 0.9990 & 1.0004 \\
\hline IL & 0.9460 & 1.0078 & 1.0105 & 0.9980 \\
\hline IN & 0.8646 & 0.9938 & 1.0114 & 0.9918 \\
\hline IA & 0.8520 & 1.0092 & 0.9990 & 1.0097 \\
\hline KS & 0.8376 & 1.0025 & 0.9980 & 1.0027 \\
\hline KY & 0.8845 & 1.0029 & 1.0028 & 1.0011 \\
\hline LA & 1.0000 & 0.9838 & 0.9838 & 1.0000 \\
\hline ME & 0.8116 & 1.0169 & 1.0113 & 1.0033 \\
\hline MD & 0.9999 & 0.9886 & 0.9886 & 1.0000 \\
\hline MI & 0.9190 & 0.9953 & 1.0078 & 0.9889 \\
\hline MN & 0.8458 & 1.0151 & 1.0073 & 1.0089 \\
\hline MS & 0.8104 & 1.0075 & 0.9990 & 1.0070 \\
\hline MO & 0.8830 & 1.0099 & 1.0162 & 0.9938 \\
\hline MT & 0.8574 & 1.0013 & 0.9934 & 1.0079 \\
\hline NE & 0.8233 & 1.0024 & 0.9970 & 1.0079 \\
\hline NV & 0.9995 & 1.0103 & 1.0103 & 1.0000 \\
\hline NH & 0.9263 & 1.0413 & 1.0201 & 1.0041 \\
\hline NJ & 1.0000 & 1.0149 & 1.0149 & 1.0000 \\
\hline NM & 1.0000 & 0.9921 & 0.9921 & 1.0000 \\
\hline NY & 0.9790 & 1.0015 & 1.0015 & 1.0000 \\
\hline NC & 0.9635 & 1.0146 & 1.0185 & 0.9983 \\
\hline ND & 0.8249 & 0.9913 & 0.9923 & 0.9832 \\
\hline $\mathrm{OH}$ & 0.8965 & 1.0067 & 1.0132 & 0.9901 \\
\hline OK & 0.9730 & 0.9944 & 0.9945 & 0.9966 \\
\hline OR & 0.8263 & 0.9972 & 1.0004 & 0.9953 \\
\hline PA & 0.8528 & 1.0081 & 1.0124 & 0.9970 \\
\hline RI & 1.0000 & 1.0015 & 1.0015 & 1.0000 \\
\hline SC & 0.9043 & 1.0090 & 1.0179 & 0.9980 \\
\hline SD & 0.7989 & 1.0000 & 0.9956 & 1.0034 \\
\hline TN & 0.8304 & 1.0117 & 1.0102 & 1.0028 \\
\hline TX & 1.0000 & 0.9950 & 0.9950 & 1.0000 \\
\hline UT & 0.8683 & 1.0033 & 0.9963 & 1.0000 \\
\hline VT & 0.7883 & 1.0188 & 1.0077 & 1.0000 \\
\hline VA & 1.0000 & 1.0001 & 1.0001 & 1.0000 \\
\hline WA & 0.9818 & 0.9997 & 1.0020 & 0.9980 \\
\hline WV & 0.7912 & 1.0049 & 0.9961 & 1.0087 \\
\hline WI & 0.8659 & 1.0065 & 1.0117 & 0.9961 \\
\hline WY & 1.0000 & 0.9947 & 0.9947 & 1.0000 \\
\hline
\end{tabular}


TABLE 4

Regression Results

\begin{tabular}{|c|c|c|c|c|c|c|}
\hline Variable & TECH & TECH & EFFCH & EFFCH & MALM & MALM \\
\hline CONSTANT & $\begin{array}{c}0.894^{* * *} \\
(.0020)\end{array}$ & $\begin{array}{l}0.846^{* * *} \\
(.0002)\end{array}$ & $\begin{array}{l}1.426^{* * *} \\
(.0001)\end{array}$ & $\begin{array}{l}1.255^{* * *} \\
(.0001)\end{array}$ & $\begin{array}{l}1.029 * * * \\
(.0051)\end{array}$ & $\begin{array}{l}0.6580^{n * * *} \\
(.0091)\end{array}$ \\
\hline COLLEGE & $\begin{array}{r}-0.017^{* *} \\
(.0324)\end{array}$ & $\begin{array}{r}-0.02^{* * *} \\
(.0016)\end{array}$ & $\begin{array}{c}0.014^{* *} \\
(.0319)\end{array}$ & $\begin{array}{l}0.009 \\
(.1787)\end{array}$ & $\begin{array}{c}-0.0002 \\
(.9831)\end{array}$ & $\begin{array}{c}-0.013^{*} \\
(.0947)\end{array}$ \\
\hline MFG & $\begin{array}{l}0.012^{* * *} \\
(.0001)\end{array}$ & $\begin{array}{l}0.008^{* * *} \\
(.0013)\end{array}$ & $\begin{array}{r}-0.0009 \\
(.6836)\end{array}$ & $\begin{array}{r}-0.0010 \\
(.6475)\end{array}$ & $\begin{array}{l}0.010^{* * *} \\
(.0081)\end{array}$ & $\begin{array}{l}0.0060^{* * *} \\
(.0024)\end{array}$ \\
\hline UNION & $\begin{array}{c}-0.029 \\
(.3010)\end{array}$ & $\begin{array}{l}0.0055 \\
(.8274)\end{array}$ & $\begin{array}{r}-0.0430^{*} \\
(.0665)\end{array}$ & $\begin{array}{r}-0.0280 \\
(.2657)\end{array}$ & $\begin{array}{r}-0.0570 \\
(.1180)\end{array}$ & $\begin{array}{r}-0.0001 \\
(.9984)\end{array}$ \\
\hline METRO & $\begin{array}{c}0.0343 \\
(.5806)\end{array}$ & $\begin{array}{c}0.0082 \\
(.8760)\end{array}$ & $\begin{array}{r}-0.0593 \\
(.2467)\end{array}$ & $\begin{array}{r}-0.0920^{*} \\
(.0838)\end{array}$ & $\begin{array}{l}0.0835 \\
(.2988)\end{array}$ & $\begin{array}{r}-0.0086 \\
(.8883)\end{array}$ \\
\hline TOP20 & $\begin{array}{r}-0.0013 \\
(.5355)\end{array}$ & $\begin{array}{c}-0.0008 \\
(.6265)\end{array}$ & $\begin{array}{r}-0.0022 \\
(.2092)\end{array}$ & $\begin{array}{c}-0.0052 \\
(.1519)\end{array}$ & $\begin{array}{r}-0.2259 \\
(.4033)\end{array}$ & $\begin{array}{c}-0.0009 \\
(.6598)\end{array}$ \\
\hline CAPPRIV & $\begin{array}{l}0.3000^{* * *} \\
(.0024)\end{array}$ & $\overline{(1430)}$ & $\begin{array}{r}-0.1122 \\
(.0424)\end{array}$ & - & $0.2481^{* *}$ & - \\
\hline CAPPUBLIC & $\begin{array}{l}0.1261 \\
(.2658)\end{array}$ & $(-3558)$ & $\begin{array}{r}-0.0850 \\
(.6483)\end{array}$ & - & -0.0661 & - \\
\hline OUTPUT & - & $\begin{array}{l}0.366^{* * *} \\
(.0001)\end{array}$ & $\overline{(.8407)}$ & 0.0136 & - & $\begin{array}{l}0.4390^{* * *} \\
(.0001)\end{array}$ \\
\hline $\mathrm{EFF}_{1977}$ & $\begin{array}{r}-0.0040 \\
(.7388)\end{array}$ & $\begin{array}{l}0.0133 \\
(.1834)\end{array}$ & $\begin{array}{r}-0.025^{* *} \\
(.0234)\end{array}$ & $\begin{array}{c}-0.030^{* * *} \\
(.0020)\end{array}$ & $\begin{array}{r}-0.044^{* *} \\
(.0122)\end{array}$ & $\begin{array}{c}-0.030^{* * *} \\
(.0098)\end{array}$ \\
\hline FEMALE & $\begin{array}{c}-0.3340 \\
(.1158)\end{array}$ & $\begin{array}{c}-0.2500 \\
(.1504)\end{array}$ & $\begin{array}{c}-0.1000 \\
(.5596)\end{array}$ & $\begin{array}{c}-0.1352 \\
(.4289)\end{array}$ & $\begin{array}{r}-0.2258 \\
(.4033)\end{array}$ & $\begin{array}{r}-0.1259 \\
(.5331)\end{array}$ \\
\hline SUNBELT & $\begin{array}{c}-0.0090^{* *} \\
(.0039)\end{array}$ & $\begin{array}{c}-0.010^{* * *} \\
(.0003)\end{array}$ & $\begin{array}{l}0.0059^{* *} \\
(.0130)\end{array}$ & $\begin{array}{l}0.0036^{*} \\
(.0708)\end{array}$ & $\begin{array}{r}-0.0028 \\
(.4321)\end{array}$ & $\begin{array}{c}-0.0060^{* *} \\
(.0150)\end{array}$ \\
\hline ADJ R ${ }^{2}$ & .558 & .684 & .243 & .201 & .419 & .653 \\
\hline $\mathrm{N}$ & 46 & 46 & 46 & 46 & 46 & 46 \\
\hline
\end{tabular}

Numbers in parentheses are the p-values of the t-test.

***.01 Significance Level

**.05 Significance Level

*.10 Significance Level

Note: Two states, Wyoming and Vermont, are excluded from these regressions because it was impossible to compute a growth rate of metropolitan population since their populations were entirely nonmetropolitan in 1977.

Table 4 gives the regression results for MALM and two of its components, $\mathrm{EFFCH}$ and TECH. Whether output growth or capital growth is used, the results are very similar. In both tables, it can be seen that the explanatory power of the $\mathrm{EFFCH}$ regression is low relative to the other two regressions.

One result from Table 4 is that technological change and TFP growth are higher in states with a higher proportion of their output in the manufacturing sector. This is not true, however, of the efficiency change regression, where the manufacturing coefficient is insignificant. This might suggest that technological change is faster in manufacturing sectors relative to nonmanufacturing sectors, leading to faster TFP growth in states with a larger percentage of their output in those sectors.

The negative sign on the coefficient of the efficiency level of a state in 1977 $\left(\mathrm{EFF}_{1977}\right)$ in both the EFFCH and the MALM equations implies a catching-up process is occurring. That is, states that were farther away from their production frontiers at the beginning of the period tended to experience faster growth in TFP 
and in efficiency during the period. In contrast, low efficiency regions in 1977 did not tend to be the leaders in the rate of growth of technological change during the period as $\mathrm{EFF}_{1977}$ is insignificant in the TECH regression.

A rather puzzling result is the negative relationship between the proportion of the population in a state with a college degree (COLLEGE) and the rate of technological change. Clearly, a positive relationship is expected between these two variables. One possible explanation may be the age structure of the college graduates in a state. Technological progress may be faster in states with more recent college graduates (ages 25 to 35, for example) than in states where the colleges graduates are somewhat older (ages 50 to 65, for example). Since the COLLEGE variable makes no distinction by age of graduates, the results could be affected if the age structures of graduates are significantly different from state to state. In contrast to the rather anomalous results for technological change, COLLEGE is positively related to efficiency change.

The dummy variable representing states in the southeast and southwest regions (SUNBELT) is negatively related to technological change but positively related to efficiency change. This indicates that states in these regions have been more successful in improving their level of efficiency (moving closer to their production frontiers) than have been other states, but SUNBELT states have lagged behind in the rate of technological change (outward movement of their production frontiers).

When the rates of growth of private and public capital are included, only the former is significant in two of the regressions (MALM and TECH). Since new technology is frequently embodied in capital, the positive relationship between TECH and CAPPRIV is expected. However, there is no evidence of a positive influence of private capital growth on efficiency change. The growth of public capital (CAPPUBLIC) is insignificant in all relevant regressions in Table 4.

When output growth (OUTPUT) is used in place of capital growth, consistent with Williams and Moomaw (1989), the growth of TFP increases as the growth rate of output increases. The effect on TFP appears to be through its positive effect on the rate of technological change as opposed to efficiency change since OUTPUT is insignificant in the EFFCH regression. The implication is that fast-growing regions may adopt new technology more readily than slowergrowing regions, and this is then reflected in faster TFP growth.

In Table 5, the average level of efficiency (EFFICIENCY) is the dependent variable. In column (1), private and public capital growth are included while in column (2), output growth is included and the capital growth variables are omitted. Since EFFICIENCY in a state is the average level over the period as opposed to a growth rate, two of the independent variables (UNIONA and METROA) were changed to levels as well (see Table 2 for definitions). In general, the regression with capital growth variables performs much better than the regression with output growth. As a result, attention will be primarily focused on regression (1) in Table 5. 
TABLE 5

Regression Results

Dependent Variable: EFFICIENCY

\begin{tabular}{lcc} 
VARIABLE & $(1)$ & $(2)$ \\
\hline CONSTANT & 3.4716 & $5.1490^{* *}$ \\
COLLEGE & $(.1140)$ & $(.0178)$ \\
& $0.1677^{* *}$ & $0.2488^{* * *}$ \\
MFG & $(.0213)$ & $(.0010)$ \\
& $-0.0373^{*}$ & -0.0245 \\
UNIONA & $(.0667)$ & $(.1763)$ \\
TOP20 & 0.0518 & 0.0382 \\
& $(.1252)$ & $(.2901)$ \\
METROA & $-0.0416^{* *}$ & -0.0261 \\
& $(.0380)$ & $(.1932)$ \\
FEMALE & $0.0256^{* *}$ & $0.0249^{*}$ \\
& $(.0430)$ & $(.0664)$ \\
CAPPRIV & $-3.4700^{* *}$ & $-3.5126^{*}$ \\
CAPPUBLIC & $(.0490)$ & $(.0645)$ \\
& $2.0253^{* *}$ & $(.0490)$ \\
OUTPUT & & - \\
SUNBELT & -0.7660 & $(.3619)$ \\
& & -0.1820 \\
ADJ R & 2 & $-.7825)$ \\
$\mathrm{N}$ & & $0.0513^{*}$ \\
\end{tabular}

A very interesting result from the first regression (column (1)) in Table 5 is the positive sign on METROA and the negative sign on TOP20. Taken together, these suggest that a greater proportion of metropolitan population in a state improves efficiency, but that in the very largest metropolitan areas, efficiency levels are less. This could perhaps be indicative of agglomeration diseconomies in the largest metropolitan areas that make it difficult for firms to attain their maximum efficiency levels. The negative coefficient on the growth of the proportion of females in the labor force offers some evidence that employees with limited experience may reduce the efficiency of the workforce. The result is the same regardless of whether output or capital growth is included.

The positive sign on COLLEGE is to be expected; the negative sign on the $\log$ of the proportion of manufacturing in output is not. The formal explanation for the latter result would be that nonmanufacturing sectors are operating closer to their production frontiers than is the manufacturing sector. Another possible explanation may be that the manufacturing sector produces an output that is not valued by the market, for example, pollution reduction. States with a relatively large manufacturing sector, therefore, may appear to be less efficient since some of its resources are being devoted to the production of a nonvalued output. When combined with the results of Table 4, this suggests that TFP growth will be higher in states with a higher proportion of their output in manufacturing, but that efficiency levels will be lower. 


\section{SUMMARY AND CONCLUSION}

Given that technological change and efficiency change are components of TFP change, it is not surprising that similar independent variables are significant in subsequent equations using TFP growth or its components as the dependent. In both cases, TFP growth and technological change are higher as the share of manufacturing increases in total output. Likewise, the faster the growth rate of private capital, the faster are TFP growth and technological change. These results are not very surprising given the critical role capital plays in boosting productivity.

The level of the efficiency of production in a state is influenced by a variety of factors. It is for this variable that metropolitan population is significant. The efficiency level of a state improves as its metropolitan population (in relative terms) increases. This is suggestive of a positive influence for agglomeration economies. However, there appears to be a limit to the advantages of metropolitanization since states with the largest metropolitan areas in the U.S. have lower efficiency levels. While education's role is not apparent for TFP growth, it has a positive and significant effect on efficiency levels. In addition, a higher proportion of manufacturing in a state's output mix boosts TFP growth and technological growth, but has a negative effect on efficiency levels. This implies that relatively more manufacturing output in a state helps to shift out the production frontier, but makes it less likely that a state operates on its frontier.

The results of this study should be of interest to individuals involved in policy making at the regional level. Despite the well-publicized shift to a service economy in the United States, it appears that manufacturing still holds the key to technological change and, therefore, TFP growth. In addition, a climate favorable to private capital formation will also be fruitful. For regions that are operating below their production frontiers, improvements in the education level of the work force, policies to improve the skills of labor force participants with limited experience, and policies to attract private capital would appear to be desirable. In addition, there is evidence that in states with very large urban areas, policies to encourage location in less densely populated regions would also improve efficiency in production.

\section{REFERENCES}

Beeson, Patricia. "Total Factor Productivity Growth and Agglomeration Economies in Manufacturing, 1959-73." Journal of Regional Science 27 (1987), 183-199.

Beeson, Patricia and Steven Husted. "Patterns and Determinants of Productive Efficiency in State Manufacturing." Journal of Regional Science 29 (1989), 15-28.

Caves, Douglas W., Laurits R. Christensen, and W. Erwin Diewert. "The Economic Theory of Index Numbers and its Measurement of Input, Output and Productivity." Econometrica 50 (1982), 1393-1414.

Domazlicky, Bruce R. and William L. Weber. "Total Factor Productivity in the Contiguous United States, 1977-86." Journal of Regional Science 37 (1997), 213-33. 
Fare, Rolfe, Shawna Grosskopf, Mary Norris and Zhongyang Zhang. "Productivity Growth, Technical Progress, and Efficiency Change in Industrialized Countries." American Economic Review 84 (1994), 66-83.

Holtz-Eakin, Douglas. "State Specific Estimates of State and Local Government Capital." Regional Science and Urban Economics 23 (1993), 185-209.

Hulten, Charles R. and Robert M. Schwab. "Regional Productivity Growth in U.S. Manufacturing, 1951-78." American Economic Review 74 (1984),152-62.

McCoy, Kim and Ronald L. Moomaw. "Determinants of Manufacturing Efficiency in Canadian Cities: A Stochastic Approach." The Review of Regional Studies 25 (1995), 317-330.

Moomaw, Ronald L. and Martin Williams. "Total Factor Productivity Growth in Manufacturing: Further Evidence from the States." Journal of Regional Science 31 (1991), 17-34.

Mullen, John K. and Martin Williams. "Explaining Total Factor Productivity Differentials in Urban Manufacturing." Journal of Urban Economics 28 (1990), 103-123.

Munnell, Alicia. "How Does Public Infrastructure Affect Regional Economic Performance?" In A. Munnell (ed.) Is There a Shortfall in Public Capital Investment? Boston, MA: Federal Reserve Bank of Boston, 1990.

U.S. Department of Commerce. Bureau of Economic Analysis. Regional Economic Information System. May 1991. (CD-ROM)

. Bureau of the Census. State and Metropolitan Area Data Book, 1982. Washington, D.C.: U.S. Government Printing Office, 1982.

U.S. Department of Labor. Handbook of Labor Statistics. Washington, D.C.: U.S. Government Printing Office, 1989.

- various issues. Geographic Profile of Employment and Unemployment.

Washington, D.C.: U.S. Government Printing Office.

Williams, Martin and Ronald L. Moomaw. "Capital and Labor Efficiencies: A Regional Analysis." Urban Studies 26 (1989), 573-585. 
